\title{
SEGMENTASI PASAR ANGKUTAN BENDI DI KOTA SOLOK
}

\author{
Eko Jundri Wendi ${ }^{1}$, Yurni Suasti ${ }^{2}$ \\ Program Studi Geografi NK \\ Fakultas Ilmu Sosial, Universitas Negeri Padang \\ Email : $\underline{\text { slkjundri@gmail.com }}$
}

\begin{abstract}
Abstrak
Penelitian ini bertujuan untuk mengetahui segmentasi pasar angkutan bendi di Kota Solok. Jenis penelitian yang digunakan adalah penelitian deskriptif dengan pendekatan kualitatif. Informan penelitian terdiri 8 orang kusir bendi, 10 orang penumpang bendi, 4 orang penumpang angkot, dan 4 orang penumpang ojek. Data penelitian diperoleh melalui wawancara dan studi dokumentasi. Hasil penelitian tentang segmentasi pasar angkutan bendi di Kota Solok yaitu : (1) Segmentasi pasar angkutan bendi adalah ibu rumah tangga, pensiuan, dan pedagang dengan pendidikan SMA sampai perguruan tinggi (2) Motivasi penumpang menggunakan angkutan bendi adalah sebagai sarana untuk rekreasi, yaitu menikmati udara sore sambil membawa anaknya berkeliling Kota Solok. Selain itu terdapat penumpang yang berprofesi sebagai pedagang warung menggunakan bendi untuk membawa barang belanjaan yang banyak. (3) Jangkauan pelayanan angkutan bendi terkonsentrasi pada tiga titik, yaitu :Depan Los Daging dengan trayek Pasar Raya-Tanah Garam-Pandan Puti, Simpang Surya melewati Pasar Raya-Batas Kota, dan Koto Panjang melewati Pasar Raya-Simpang Rumbio. Angkutan bendi tidak memiliki jalur khusus, tapi tergantung pada permintaan dari penumpang.
\end{abstract}

Kata Kunci : Bendi, Segmentasi, Motivasi, Jangkauan.

\begin{abstract}
This study aims to find out the segmentation of the bendi freight market in Solok City. The type of research used is descriptive research with qualitative approach. The research informant consisted of 8 custodians of bend, 10 passengers of bendi, 4 passengers of angkot, and 4 passengers of motorcycle taxi. Research data was obtained through interview and documentation study. The results of research on segmentation of bend market in Solok city are: (1) bend market segmentation is housewife, pensiuan, and trader with high school and college education (2) passenger motivation using bendi transportation is as a means for recreation, the afternoon air while bringing his son around Solok city, besides there are passengers who use bendi to bring goods purchased from Solok Market for resale (3) The reach of bendi transport services is concentrated in three points, namely: Home Los Meat with route Raya-Tanah Garam-Pandan Puti, Simpang Surya passes Pasar RayaBatas Kota, and Koto Panjang passes Pasar Raya-Simpang Rumbio. Transport of bendi does not have a special line, but depends on the demand from passengers.

Keywords: Bendi, Segmentation, Motivation, Range.
\end{abstract}

${ }^{1}$ Mahasiswa Program Studi Geografi NK untuk Wisuda Maret 2018

${ }^{2}$ Pembimbing I : Dra. Yurni Suasti, M.Si 


\section{PENDAHULUAN}

Kehidupan manusia dibatasi oleh ruang atau wilayah, antara suatu wilayah dengan wilayah yang lain yang dibatasi dengan faktor-faktor alamiah atau kondisi fisik seperti gunung, sungai, dan laut serta faktor sosial seperti pendidikan, sosial, ekonomi, budaya dalam memenuhi kebutuhannya. Manusia mengalami pergerakan atau mobilitas kegiatan, mobilitas penduduk dan perjalanan tersebut ditandai dengan kebutuhan terhadap alat angkutan atau sarana transportasi.

Dalam ilmu geografi, transportasi merupakan alat yang digunakan untuk mengangkut/memindahkan barang atau orang dari suatu tempat ke tempat yang lainnya yang dipengaruhi oleh fenomena geografi yaitu aspek keruangan, jarak, iklim dan relief muka bumi. Sedangkan ditinjau dari ilmu ekonomi mikro, transportasi digunakan sebagai alat untuk memperoleh keuntungan ekonomis dalam berbagai usaha dan hubungan kemasyarakatan. Di sini terdapat dua pihak yang berhubungan. Di satu pihak pengusaha angkutan yang memandang angkutan sebagai produk jasa untuk dijual kepada pemakai jasa dengan mengharapkan keuntungan. Di lain pihak adalah konsumen yang memanfaatkan jasa angkutan dengan membayar biaya operasi dalam bentuk ongkos sesuai dengan tarif yang telah ditetapkan.
Kendaraan menurut jenis pelayanan dapat dibagi menjadi dua kelompok, yaitu kendaraan yang beroperasi di jurusan tetap dengan tarif yang telah ditetapkan seperti bus kota dan angkot, selain itu ada juga kendaraan yang melayani ke segala jurusan yang dikehendaki penumpang dengan tarif yang ditentukan melalui tawar menawar seperti becak, betor, ojek, dan bendi.

Kedua jenis pelayanan angkutan di kota ini dibutuhkan oleh masyarakat, selain pelayanan dengan trayek tetap yang dilakukan oleh bus, masih perlu pelayanan lain yang fleksibel, khususnya pelayanan dari rumah kerumah, karena laju pertumbuhan penduduk Kota Solok dari tahun 2000 sampai 2011 mengalami pertumbuhan yang sangat pesat.

Seiring bertambahnya jumlah penduduk dan perkembangan Kota Solok yang semakin pesat serta dengan tersedianya fasilitas kota yang lebih sempurna, mengakibatkan kebutuhan akan sarana transportasi semakin meningkat. Sementara itu, perluasan kota menimbulkan kecendrungan pemukiman jauh dari tempat kerja atau pusat kegiatan yang masih terdapatnya lokasi-lokasi yang tidak terjangkau oleh transportasi yang ada. Oleh karena itu, kebutuhan masyarakat terhadap angkutan yang serba cepat, praktis dan ekonomis tidak dapat dihindarkan. 
Kamaluddin

$(2003,83)$

transportasi berasal dari bahasa Latin transportare, trans yang artinya seberang, antar atau ke sebelah dan portare yang artinya mengangkat. Jadi, transportasi berarti mengangkut ke seberang, yang berarti suatu kegiatan memindahkan barang atau orang dari suatu tempat ke tempat yang lainnya.

Pengertian transportasi menurut Steenbrink (1974), transportasi adalah perpindahan orang atau barang dengan menggunakan alat atau kendaraan dari dan ke tempattempat yang terpisah secara geografis. Menurut Morlok (1978), transportasi didefinisikan sebagai kegiatan memindahkan atau mengangkut sesuatu dari suatu tempat ke tempat lain. Sedangkan menurut Bowersox (1981), transportasi adalah perpindahan barang atau penumpang dari suatu tempat ke tempat lain, dimana produk dipindahkan ke tempat tujuan dibutuhkan. Dan secara umum transportasi adalah suatu kegiatan memindahkan sesuatu (barang dan/ atau barang) dari suatu tempat ke tempat lain, baik dengan atau tanpa sarana.

Hurst dalam Anwar (1999:84) mengemukakan bahwa transportation is measure of the relation between areas (transportasi adalah suatu kegiatan yang menghubungkan suatu daerah dengan daerah lain). Hurst juga mengemukakan bahwa kegiatan transportasi muncul karena tiga faktor geografis yaitu : 1) jarak (distance), 2) melengkapi kebutuhan (complementary), 3) kesempatan untuk intervensi (intervening opportunity).

Jarak menyebabkan aktivitas berpergian dari suatu tempat ke tempat lainnya di muka bumi. Jarak menurut Hurst dalam Anwar (1999:86) ada dua macam yaitu : jarak absolut dan jarak relatif. Jarak absolut yaitu jarak yang sebenarnya antara suatu tempat ke tempat yang lainnya. Jarak relatif yaitu mempunyai jarak absolut yang sama tetapi kecepatan berdasarkan benda yang digunakan. Aktivitas bepergian ini dilakukan manusia dimulai dengan cara yang sederhana seperti dengan menggunakan hewan, kereta, gerobak sampai dengan menggunakan alat angkutan modern dan canggih dengan teknologi tinggi.

Antara suatu lokasi dengan lokasi yang lain terdapat perbedaan sumber daya alamnya (natural resources). Akibat perbedaan sumber daya alam itu, maka muncul usaha manusia untuk saling melengkapi. Usaha ini dapat dilakkan melalui usaha angkutan yang disebut dengan transportasi. Hurst dalam Anwar (1999:88) juga mengemukakan bahwa suatu usaha untuk saling melengkapi tidak hanya akibat perbedaan sumber daya alam saja juga karena perbedaan kondisi sosial, budaya. Antara lain pendidikan, politik, ekonomi dan adat istiadat. Transportasi muncul karena kesempatan untuk berintervensi. Intervening sifatnya sebagai kegiatan pengarahan manusia dari suatu daerah 
ke daerah lain guna berbagai kepentingan.

Kamaludin dalam Anwar (1999:90) mengemukakan bahwa transportasi terdiri dari empat unsur yaitu jalan, alat angkutan, tenaga penggerak dan terminal. Jalan ditujukan dan disediakan sebagai basis untuk alat angkutan untuk bergerak dari suatu tempat ke tempat tujuannya. Berdasarkan beberapa pendapat di atas, disimpulkan bahwa transportasi adalah suatu kegiatan yang memindahkan barang atau manusia dari satu tempat ke tempat lainnya. Dalam transportasi ada empat unsur yang harus terpenuhi yaitu jalan, alat angkutan, terminal dan tenaga penggerak.

Warpani (1990:53), angkutan umum atau publik menurut kamus tata ruang adalah alat angkut penumpang yang diperuntukkan bagi masyarakat umum. Angkutan umum penumpang adalah angkutan penumpang yang dilakukan dengan sistem sewa atau bayar. Jadi angkutan umum adalah suatu sarana transportasi yang membawa penumpang dari suatu tempat ke tempat lain dengan sistem sewa atau bayar.

Terdapat empat jenis alat transportasi di Kota Solok, yaitu angkot, betor, ojek dan bendi. Daerah yang dilewati oleh jalur angkot di Kota Solok hanya rute Pasar Raya-Tanah Garam. Selain itu terdapat angkot yang melayani daerah Kabupaten Solok, dengan rute Pasar Raya-Koto Baru.
Adapun daerah yang dilewati angkot rute Pasar Raya-Koto Baru adalah Koto Baru, Selayo, Simpang By Pass, Lukah Pandan, IX Korong, Sinapa Piliang, Pasar Raya. Berdasarkan hal tersebut diketahui banyak daerah yang tidak terjangkau oleh angkot, seperti daerah Pandan, Air Mati, Simpang Rumbio, Tanjung Paku, Kampung Baru, Kampung Jawa, Laing, Ampang Kualo sehingga dibutuhkan moda transportasi yang dapat menjangkau jalur yang tidak dilewati oleh angkot, seperti ojek, betor maupun bendi. bendi merupakan alat angkutan tradisional kereta roda yang ditarik oleh kuda dikenal juga dengan dokar atau andong, melayani angkutan jarak dekat terutama di pusat kota. Munculnya bendi di Kota Solok, sepanjang sejarah angkutan tradisional di Sumatera Barat sulit diketahui dengan pasti sejak kapan dan darimana asal mula bendi masuk ke Sumatera Barat. Bendi sebagai peninggalan masa lalu terlihat mencerminkan keagungannya, dulunya angkutan bendi dimiliki secara pribadi dan digunakan untuk kepentingan pribadi dengan jumlah yang terabatas oleh golongan tertentu dalam masyarakat, yaitu golongan bangsawan. Bendi meraih popularitasnya pada saat jasa oplet belum lancar serta angkutan ojek yang belum sebanyak sekarang.

Pekerjaan sebagai kusir bendi merupakan alternatif lapangan pekerjaan bagi penduduk yang memiliki keahlian rendah. Angkutan 
bendi merupakan salah satu aset budaya dan pariwisata khususnya di Propinsi Sumatera Barat. Kenyataannya di lapangan menunjukan perkembangan angkutan bendi mulai berkurang atau bukan merupakan alat angkutan utama bagi masyarakat Kota Solok. Hal itu disebabkan karena kebutuhan masyarakat terhadap angkutan yang serba cepat praktis dan ekonomis, kebutuhan tersebut dapat di penuhi oleh angkutan modern seperti betor dan ojek.

Betor dan ojek merupakan pesaing utama angkutan bendi selain angkutan modern lainnya, masyarakat lebih cendrung memilih menaiki betor atau ojek di bandingkan dengan bendi, karena betor dan ojek dinilai lebih cepat dan ekonomis dibanding angkutan bendi. Hal ini menyebabkan berkurangnya pendapatan para kusir bendi, walaupun demikian masih ada masyarakat yang memilih bendi sebagai sarana angkutan walau jumlahnya sedikit. Selain itu masih ada kusir bendi yang masih bertahan sebagai kusir walaupun pendapatannya tidak mampu lagi memenuhi kebutuhan sehari hari.

Segmentasi bendi di tengah tengah angkutan modern perlu di perhatikan di Kota Solok. Segmentasi pasar menurut Philip Kotler (2001:94) adalah pembagian sebuah pasar menjadi beberapa kelompok pembeli yang berbeda. Segmentasi pasar dapat dimaksudkan sebagai pembagian pasar yang berbeda-beda (heterogen) menjadi kelompok-kelompok pasar yang homogen, di mana setiap kelompoknya bisa ditargetkan untuk memasarkan suatu produk sesuai dengan kebutuhan, keinginan, ataupun karakteristik pembeli yang ada di pasar tersebut.

Segmentasi pasar adalah kegiatan membagi suatu pasar menjadi kelompok kelompok pembeli yang berbeda. Segmentasi pasar juga dapat di artikan sebagai proses pengidentifikasian dan menganalisis para pembeli di pasar produk, menganalisis perbedaan antara pembeli di pasar.

Di sisi lain siapa saja masyarakat yang akan menaiki alat angkutan bendi di tengah-tengah sarana transportasi yang cepat dan ekonomis yang tidak dapat dipenuhi oleh angkutan bendi. Masyarakat lebih cendrung memilih angkutan modern seperti betor dan ojek sebagai sarana angkutan.

Permasalahan keberadaan bendi sebagaimana dikemukakan diatas sangat menarik untuk diteliti, siapa segmentasi pasar angkutan bendi, apa alasan penumpang menggunakan angkutan bendi, dimana jalur operasi angkutan bendi di Kota Solok. Berdasarkan hal di atas perlu suatu kajian menyeluruh tentang angkutan bendi yang dituangkan dalam suatu judul penelitian yaitu "Segmentasi Pasar Angkutan Tradisional Bendi di Kota Solok". 


\section{METODE PENELITIAN}

Jenis penelitian ini adalah penelitian deskriptif dengan pendekatan kualitatif. Penelitian ini dilakukan di Pasar Raya Kota Solok, tepatnya di Kecamatan Tanjung Harapan Kelurahan Pasar Pandan Air Mati dengan angkutan bendi berjumlah 15 unit. Penelitian ini dilakukan selama 1 bulan yaitu pada tanggal 20 Juni sampai 15 Juli 2017.

Adapun yang menjadi subjek dalam penelitian ini adalah kusir bendi, penumpang angkutan bendi, penumpang angkutan kota (angkot) dan penumpang ojek.

Teknik pengumpulan data dalam penelitian ini adalah dengan wawancara (interview). Wawancara adalah suatu kegiatan yang dilakukan untuk mendapatkan informasi secara langsung dengan mengungkapkan pertanyaan-pertanyaan kepada informan untuk memperoleh data dan informasi yang diinginkan. Teknik wawancara yang dilakukan adalah sebagai berikut : 1) Wawancara bebas bertujuan untuk memperoleh keterangan yang bersifat informal atau tidak resmi yang biasanya terwujud dalam pembicaraan-pembicaraan yang diberikan diarahkan pada data yang diinginkan. 2) Wawancara terstruktur, bertujuan memperoleh keterangan khusus yang berkaitan dengan masalah penelitian yang disusun dalam bentuk instrumen penelitian berupa pedoman wawancara dan kemudian direkam melalui kaset rekaman.
Analisa data dilakukan melalui prosedur atau beberapa tahap antara lain sebagai berikut: 1) Reduksi Data, Reduksi data merupakan proses pemusatan perhatian pada penyederhanaan, pengabstrakan dan transformasi data kasar yang muncul dari catatan tertulis di lapangan. Reduksi data berlangsung terus menerus selama penelitian berlangsung. Jadi reduksi data adalah bentuk analisis yang menggolongkan, membuang yang tidak perlu dan mengorganisasikan data sehingga kesimpulan-kesimpulan akhir dapat ditarik. 2) Interpretasi Data, Interpretasi data adalah data yang diperoleh dari mencari makna yang terkandung didalamnya kemudian dipaparkan dengan mengunakan katakata dan kalimat yang mudah dipahami. 3) Penarikan Kesimpulan Dalam penelitian ini peneliti berusaha untuk mendapatkan informasi mengenai variabel yang diteliti. Jadi, data yang diperoleh dari lapangan yang telah dikumpulkan dan analisis ditarik kesimpulannya dan akhirnya akan menjadi hasil peneliti.

Adapun Teknik Pemeriksaan Keabsahan Data dilakukan dengan cara : 1)Triangulasi, Untuk mendapatkan data yang valid peneliti menggunakan triangulasi data. Triangulasi data dilakukan dengan mengajukan pertanyaan yang sama kepada informan yang berbeda, sampai diperoleh data yang sama dari informan tersebut, sehingga ditarik 
kesimpulan dapat diperoleh dan di pertanggungjawabkan secara metodelogis. Peneliti mewancarai 4 orang penumpang angkot dan 4 orang penumpang ojek dengan mengajukan pertanyaan yang sama, sehingga data yang diperoleh di lapangan lebih akurat. Selanjutnya mengkonfirmasi data hasil wawancara dengan melihat data di lapangan lalu melakukan kegiatan cek terhadap data itu sehingga dapat diperoleh kesahihan data tersebut. 2) Pemeriksaan Teman Sejawat, pemeriksaan teman sejawat bertujuan untuk melihat kekuatan dan kelemahan tentang hasil akhir sementara yang diperoleh dari penelitian, hal ini dapat dilakukan dalam bentuk analitik dengan teman sejawat.

\section{HASIL DAN PEMBAHASAN}

\section{Segmentasi Pasar Angkutan Bendi}

Karakteristik demografi segmentasi pasar angkutan bendi diketahui bahwa penumpang angkutan bendi berasal dari latar belakang usia yang beragam, bahkan penumpang yang sudah tua. Pada umumnya penumpang angkutan bendi beragama Islam. Penumpang angkutan bendi juga berasal dari berbagai kalangan, mulai dari Ibu Rumah Tangga, Pelajar, Pensiunan Guru, Pedagang, dan Karyawan.

Latar belakang pendidikan penumpang angkutan bendi juga beragam mulai dari pelajar SD, pelajar SMP, tamatan SMA, dan D3. Bendi tidak dijadikan sebagai sarana transportasi utama, tapi bendi digunakan hanya pada saat tertentu seperti jalan-jalan sore menikmati udara Kota Solok.

Dari hasil penelitian di lapangan diketahui bahwa minat penumpang angkutan bendi jika dibanding dengan penumpang angkot dan ojek sangat sedikit. Dari sekian pengunjung Pasar Raya Kota Solok terdapat $2,08 \%$ penumpang yang menggunakan bendi sebagai sarana transportasi, $5,87 \%$ penumpang menggunakan angkot dan 26,11\% penumpang menggunakan ojek, sisanya sebanyak 65,93\% menggunakan kendaraan pribadi.

Menurut Phlip Khotler (1994:113) ) segmentasi yaitu pasar yang terdiri dari beberapa konsumen dan para konsumen tersebut berada dalam satu atau atau beberapa kelompok. Mereka bisa berbeda dalam keinginan, sumber daya, lokasi geografis, sikap membeli dan pelaksanaan pembelian mereka.

Pola dasar segmentasi pasar menurut Philip Khotler adalah segmentasi geografi : perlu membagi pasar kedalam unit unit geografis yang berbeda seperti, negara negara bagian, propinsi, wilayah, daerah, kota maupun desa, dan segmentasi demografi : pembagian pasar ke dalam kelompok kelompok berdasarkan variabel variabel demografi, seperti usia, jenis kelamin, jumlah keluarga, pendapatan, pekerjaan, pendidikan, 
agama, ras, dan kewarganegaraan/kebangsaan.Variabel variabel demografi, merupakan dasar paling popular untuk membedakan kelompok konsumen.

Berdasarkan teori ini dalam kenyataan dilapangan segmentasi pasar angkutan bendi dibedakan berdasarkan, pembagian pasar ke dalam kelompok kelompok berdasarkan variabel variabel demografi, seperti usia, jenis kelamin, jumlah keluarga, pendapatan, pekerjaan, pendidikan, agama, ras, dan kewarganegaraan/kebangsaan.

Beberapa alasan mengapa demografi sering digunakan dalam segmentasi pasar, segementasi terdiri dari beberapa variabel seperti usia, jenis kelamin, pekerjaan, dan lainya, sehingga dapat di ketahui kebutuhan dan keinginan konsumen yang berbeda beda pada setiap variabel tersebut. Demografi memberikan suatu pemahaman tentang trend yang terjadi. Meski tidak dapat di gunakan untuk meramalkan perilaku konsumen, demografi dapat digunakan untuk melihat perubahan permintaan aneka produk.

\section{Motivasi Penumpang Menggunakan Angkutan Bendi.}

Dari hasil penelitian diketahui bahwa masyarakat tidak menggunakan angkutan bendi sebagai sarana transportasi sehari-hari. Motivasi penumpang menggunakan angkutan bendi adalah sebagai sarana hiburan.
Alasan penumpang menggunakan bendi adalah untuk menikmati udara sore sambil membawa anaknya berkeliling Kota Solok, selain itu terdapat penumpang yang menggunakan bendi untuk membawa barang belanjaan yang dibeli dari pasar Solok untuk dijual kembali, penumpang tersebut berasal dari luar kota.

Motivasi penumpang angkutan kota (angkot) menaiki bendi hampir sama dengan penumpang setia bendi yaitu bersantai menikmati udara sore dan membawa anak di tambah lagi dengan penumpang yang membawa barang belanjaan dalam jumlah besar.

Pada umumnya penumpang angkot yang menaiki bendi berpendapat bahwa angkutan kota (angkot) lebih efektif daripada bendi. Dilihat dari segi tarif, angkutan kota (angkot) tarifnya lebih murah dibandingkan dengan bendi, dari segi waktu juga angkutan kota (angkot) lebih cepat.

Motivasi penumpang ojek menaiki bendi juga hampir sama dengan penumpang setia bendi yaitu bersantai menikmati udara sore dan membawa anak. Ojek dinilai lebih unggul dalam beberapa aspek dibanding bendi, salah satu keunggulannya yaitu ojek terdapat dimana-mana, sedangkan bendi hanya terdapat di Pasar Raya. Selain itu ojek juga dapat melewati jalur yang tidak dapat dilewati oleh bendi seperti gang kecil. 
Keberadaan ojek dan angkot cukup berpengaruh terhadap minat penumpang menaiki angkutan bendi, karena angkot dan ojek lebih unggul dari segi kecepatan. Walaupun kalah dalam hal kecepatan, namun angkutan bendi memiliki keunggulan dari segi lain. Angkutan bendi sangat tepat digunakan untuk bersantai menikmati udara sore, pada umumnya setuju untuk bendi tetap di pertahankan sebagai aset budaya.

Motivasi penumpang menurut Warpani (1990) ditinjau dari pemenuhan akan kebutuhan mobilitasnya, masyarakat perkotaan di bagi menjadi dua kelompok yaitu : choice dan captive. Kelompok choice yaitu sekelompok orang yang mempunyai pilihan dalam pemenuhan kebutuhan mobilitasnya, yaitu pilihan menggunakan kendaraan pribadi maupun kendaraan umum. Kelompok captive yaitu sekelompok orang yang tergantung pada angkutan umum untuk pemenuhan kebutuhan mobilitasnya.

Berdasarkan teori diatas dapat disimpulkan bahwa penumpang angkutan bendi termasuk kedalam kelompok choice. Hal ini disebabkan karena penumpang angkutan bendi mempunyai pilihan dalam memenuhi kebutuhan mobilitasnya, yaitu pilihan dalam menggunakan kendaraan pribadi atau menggunakan kendaraan umum seperti angkutan bendi. Adapun motivasi penumpang menggunakan angkutan bendi pada umumnya karena ingin bersantai menikmati udara sore, selain itu rute angkutan bendi lebih fleksibel, dibandingkan dengan kendaraan umum lainnya.

\section{Jangkauan Operasi Angkutan Bendi di Kota Solok}

Berdasarkan hasil

wawancara dengan kusir bendi diketahui bahwa angkutan bendi mulai beroperasi dari jam 11.00-17.00 WIB. Angkutan bendi terkonsentrasi pada tiga titik, yaitu : a) Depan Los Daging, Jalur operasi angkutan bendi yang terdapat di Los Daging melewati Pasar Raya-Tanah Garam-Pandan Puti. b)Simpang Surya, Jalur operasi angkutan bendi yang terdapat di Simpang Surya melewati Pasar RayaBatas Kota. c) Koto Panjang, Jalur operasi angkutan bendi yang terdapat di Koto Panjang melewati Pasar RayaSimpang Rumbio.

Kusir bendi telah menjalani profesinya selama 60 tahun. Keberadaan ojek di Kota Solok cukup berpengaruh terhadap minat masyarakat menggunakan angkutan bendi, karena ojek dinilai lebih efisien dalam segi waktu. Meskipun minat masyarakat menggunakan bendi menurun, para kusir bendi tetap setia menekuni profesinya karena tidak memiliki keahlian lain selain menjadi kusir bendi, ditambah lagi dengan usia nya yang sudah tua. Angkutan bendi tidak memiliki jalur khusus, tapi tergantung pada permintaan dari penumpang. Jalur terdekat yang dilalui 
oleh angkutan bendi adalah didaerah yang berjarak satu kilometer dari pangkalan, sedangkan jalur terjauh yang dilalui oleh angkutan bendi adalah batas kota.

Jangkauan pelayanan transportasi dapat diartikan sebagai batas batas geografi pelayanan yang di berikan oleh transportasi kepada pengguna transportasi tersebut. Batas geografis pelayanan transportasi ini di sebut juga sebagai wilayah operasi suatu sistem transportasi. Ada pelayanan sistem transportasi yang secara geografis hanya menjangkau wilayah pedesaan, dan ada juga yang melayani wilayah perkotaan yang hanya menyediakan pelayanan untuk lokasi asal dan tujuan dalam kota itu saja. Selain itu, ada juga sistem transportasi yang lokasi asal dan tujuan nya telah melampaui batas kota yaitu hingga kekota lain di dalam satu propinsi.

Berdasarkan teori ini diketahui bahwa jangkauan pelayanan angkutan bendi meliputi batas-batas geografis pelayanan yang diberikan angkutan bendi terhadap penumpang. Wilayah jangkauan pelayanan angkutan bendi hanya melayani daerah perkotaan. Adapun wilayah jangkauan pelayanan angkutan bendi terkonsentrasi pada tiga titik, yaitu :Depan Los Daging dengan trayek Pasar Raya-Tanah Garam-Pandan Puti, Simpang Surya melewati Pasar Raya-Batas Kota, dan Koto Panjang jalur operasi angkutan bendi yang terdapat di Koto Panjang melewati Pasar Raya-Simpang Rumbio.

\section{PENUTUP}

\section{Simpulan}

Segmentasi pasar angkutan bendi berasal dari latar belakang usia dan profesi, mulai dari Ibu Rumah Tangga, Pensiunan Guru, dan Pedagang. Latar belakang pendidikan penumpang angkutan bendi juga beragam mulai dari tamatan SMA, D3 dan tamatan S1. Pada umumnya penumpang angkutan bendi tidak menjadikan bendi sebagai sarana transportasi utama, tapi bendi digunakan hanya pada saat tertentu seperti jalan-jalan sore menikmati udara Kota Solok.

Motivasi penumpang menggunakan angkutan bendi adalah sebagai sarana hiburan, yaitu menikmati udara sore sambil membawa anaknya berkeliling Kota Solok, selain itu terdapat penumpang yang menggunakan bendi untuk membawa barang belanjaan yang dibeli dari pasar Solok untuk dijual kembali, penumpang tersebut berasal dari luar kota.

Jangkauan pelayanan angkutan bendi terkonsentrasi pada tiga titik, yaitu : Depan Los Daging dengan trayek Pasar Raya-Tanah GaramPandan Puti, Simpang Surya melewati Pasar Raya-Batas Kota, dan Koto Panjang melewati Pasar RayaSimpang Rumbio. Angkutan bendi tidak memiliki jalur khusus, tapi 
tergantung pada permintaan dari penumpang. Jalur terdekat yang dilalui oleh angkutan bendi adalah didaerah yang berjarak satu kilometer dari pangkalan, sedangkan jalur terjauh yang dilalui oleh angkutan bendi adalah batas kota.

\section{Saran}

Keberadaan angkutan bendi
harus dilestarikan karena angkutan
bendi merupakan aset budaya
Minangkabau. Selain digunakan sebagai sarana transportasi angkutan bendi juga digunakan sebagai sarana rekreasi. Pemerintah juga harus memperhatikan kesejahteraan kusir bendi, karena angkutan bendi selain sebagai aset budaya, angkutan bendi juga masih memiliki penumpang setia yang menggunakan bendi.

\section{DAFTAR PUSTAKA}

Anwar, Prabu. 1999. Transportasi Dan Pengembangan Wilayah.Jakarta: Graha Ilmu.

Bowersox, C. 1981. Introduction to Transportation. New York: MacmillanPublishing Co, Inc.

Kamaluddin, Rustian. 2003. Ekonomi Transportasi : Karakteristik, teori, dan kebijakan, Ghalia Indonesia : Jakarta

Kotler Philip. 1994. Marketing management Analysis, planning, Implementation, and control.

Kotler, Philip. 2001. Prinsip-prinsip Pemasaran. Jakarta : PT Gelora Aksara Pratama

Morlok, Edward K. 1978. Pengantar Teknik dan Perencanaan Transportasi : University of Pennsyvania

Steenbrink. 1974. Optimization of Transport Networks. Tugas Akhir Universitas Jendral Soedirman, Purwokerto.

Warpani,S. 1990. Merencanakan Sistem Pengangkutan.

Bandung. ITB 